\title{
Holding her hand
}

I do not know where my road is taking me, but I walk better when my hand holds yours.

\section{— Alfred de Musset}

\section{T ie beside me. Hold my hand." Nicole's words during her last days.}

She was 60 and had been my wife for 38 years. The disease plagued her for almost 10 years. Mutilating surgery, radiotherapy and long-term chemotherapy brought remission for six years. Healthy and busy years conferred on us the impression of cure. Annual tests reminded us of what we were trying to ignore. We were wrong. It came back.

Nicole's last two years of life were governed by disease progression, aggressive treatments, debilitating side effects, progressive loss of her energy, but also, family activities and the joy of becoming a grandmother. Moments of fear and hope, fight and flight, rage and acceptance, sorrow and joy, tears and laughter, winces and smiles, diminished courage, a blurred future, slow pace of life, confidences, prayers, closeness, friendship, intimacy, love.

Minus 2 months. Major side effects lead to discontinuation of treatments and necessary reinvestigation. Increased anxiety. Living one day at the time.

Minus 1 month. The disaster is confirmed: countless bone metastases, almost no functioning liver and no more possible treatment. Denying is no more a possibility. Terminal illness is in our home. We cherish available time and fear running time. Paradoxically, pending end of life gives us the gift of precious days: days to be true, days to look at others differently, days to think about life and death, days to live and love fully, days to "be" completely.

Minus 1 week. Hospitalization for drainage of ascites. Nicole's decision to come back home. Our children's and my commitment to take care of her. At her physician's suggestion, early celebration of Christmas with our two children, their significant others and our two grandchildren: happiness of being

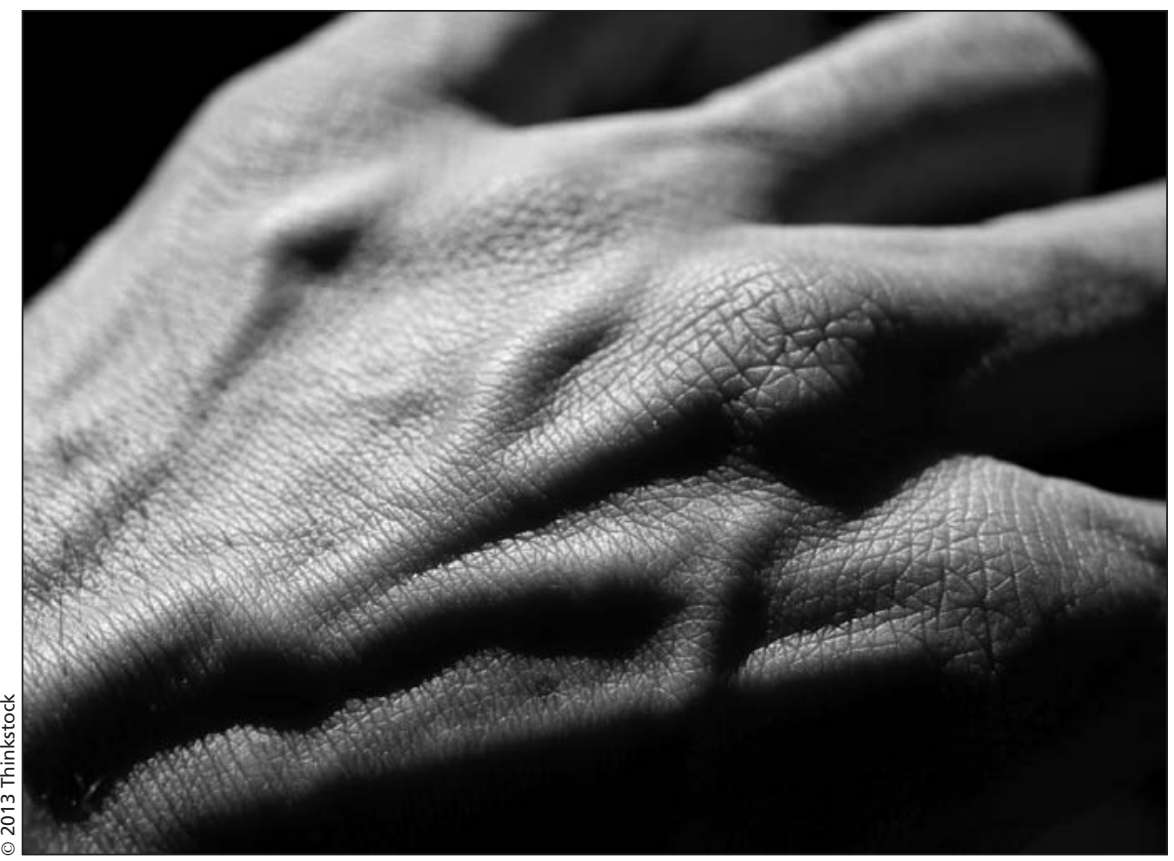

close together; sadness of seeing Nicole lying on the couch; laughs, tears, pictures. Unforgettable memories.

Nicole is suffering both in body (hugging her is impossible because of bone pain) and soul. "It is over. We stop. Hold my hand," is what she repeatedly says in her last days. We do so, hoping that her walk on the frightening road to the end of life will be soothed. Nicole, through her acceptance and serenity, holds our hands, helping us on our road of letting her go. Her physicians hold her and our hands through commitment, expertise, sharing, listening, sensibility, respect at all time. Through our faith and prayers, God holds our hands bringing peace to Nicole and giving us the strength to progressively ... leave her hand.

Last 4 days. Nicole stays in her (our) bed, surrounded by us, affectionately caressing her, trying to say goodbye and to give her permission to leave. Our priest's visit seems to give her peace. Help from us enables her to eat, drink, vomit, move. Controlled physical pain. Suffering souls. No impatience. Staying together, quiet and silent.

Minus 1 day. "Her life has to be counted in hours - 24 making 1 day," says her physician. She will make 25. A quiet night, but so much tiredness. Last confidences whispered "take care of our children and grandchildren." Lasts "I love you ... me too." Consciousness progressively leaving her.

Minus 2 hours. Increased agitation, difficult breathing. Geneviève says: "Dad, we should give mom the distress medication.” Deny. Her physician had said that it would calm her, but not bring her death. Remembrance that three years ago, my mom died four hours after receiving a similar medication. My action, her death, could they be linked? Acceptable? Forgivable? Geneviève and Hugues repeat together: 


\section{Patient's request}

My body is wrecked;

My mind is blurred,

My soul is sad.

I have a disease,

I am ill,

I live all of this through my person.

Anxiety and sorrow overcome me,

Conscious and unconscious,

Profound and painful.

I do not know where I am going.

Consider my disease and illness.

Do the best with your expertise,

Do the best with your limits,

Share them with me.

I do not ask of you the impossible.

But always, convince me that you care,

Like a friend who holds my hand,

Sometimes even without saying a word.

I will walk better the road of my life ... till its end.

Editor's note: The content of this poem was discussed between Nicole Bolduc and Paul Grand'Maison during Nicole's last weeks of life. Initially written in French, it summarizes Nicole's perception and epitomizes the deep sense of medicine and of the doctor-patient relationship, specifically at the end of life. Nicole Bolduc, Inf MSc, was an associate professor in the School of Nursing, Faculté de médecine et des sciences de la santé, Université de Sherbrooke.
"Dad, we must give mom the medication." I give two injections, Geneviève the other. She improves. She sleeps almost two hours ... so calmly; no agitation, no anxiety, no pain, no consciousness.

Minus 8 minutes. "Dad, her breathing is changing." Closer to her, as if this is possible, without saying a word, knowing that the end was coming, we listen, during seven or eight minutes, to her progressively vanishing breath.

Time 0. "One minute without a breath," I say. "Three minutes. Five minutes. Mom is dead." No more breath. No more life in her. In her white T-shirt, curled in our large bed, Nicole dies calmly, her mother, her two children, their significant others and myself beside her. Nicole, a spouse, a friend and a lover for 38 years, a mother for 36 years, a grandmother for 18 months, has gone to another world. Her breast cancer is over.

Paul Grand'Maison MD MSC

Professor

Faculté de médecine et des sciences de la santé

Université de Sherbrooke

Sherbrooke, Que.

Dedication: This article is dedicated to my wife, Nicole Bolduc, who died in my arms on December 14, 2011.

CMAJ 2013. DOI:10.1503/cmaj.121308

\section{More Humanities online}

\section{Media}

Granta: Medicine (Granta Publications; 2012) Granta, one of the world's most respected literary journals, delves into the medical humanities with this fine collection of stories from the likes of Alice Munro and M.J. Hyland. - Debra Martens, London, UK

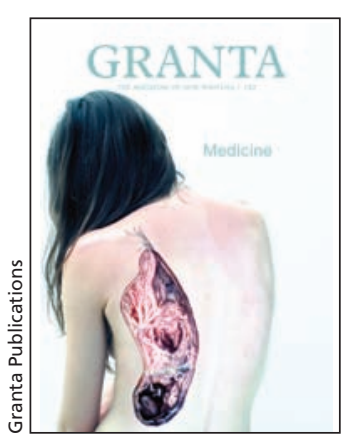

\section{Books}

Assisted Death: A Study in Ethics \& Law, by. L.W. Sumner (Oxford University Press; 2011). Under certain circumstances, physicians have a role to fill in helping cer- tain patients end their lives, either through assisted suicide or voluntary euthanasia. - Dennis Rosen, Boston, Mass.

Pharmageddon, by David Healy (University of California Press; 2011). This renowned pharma watchdog contends that physicians have allowed pharmaceutical marketing to fundamentally alter the practice of medicine. Navindra Persaud, Toronto, Ont.

The Cure for Everything! Untangling the Twisted Messages About Health, Fitness and Happiness, by Timothy Caulfield (Viking Canada; 2012). Is there a cure for everything? Intrepid lawyer and human guinea pig, Timothy Caulfield embarks on a year-long health walkabout in the land of outrageous claims. - Yoni Freedhoff MD, Ottawa, Ont.

CMAJ 2013. DOI:10.1503/cmaj.130446 